\title{
EFEITOS DE SENTIDO NA TIRINHA DE CALVIN \& HOBBES
}

\author{
Danilo Nascimento dos Santos (Uninove) \\ Bárbara Pereira de Azevedo (Uninove)
}

Nosso trabalho tem como objetivo geral analisar os efeitos de sentido em uma das tirinhas de Calvin \& Hobbes, feita pelo cartunista William B. Watterson II, por meio das categorias de discurso: condições sócio-históricas de análise do discurso; as cenas de enunciação: englobante, genérica e cenografia; ethos discursivo e o interdiscurso. Como objetivos específicos temos: demonstrar meios de interpretação do texto com o intuito de abranger os diversos pontos de vista; relacionar o conteúdo da tirinha com as condições em que a nossa sociedade está inserida. Com isso, nosso problema de pesquisa é questionar: por meio da análise do ethos que o enunciador projeta, quais são os efeitos de sentido que demonstram a necessidade de preservação do meio-ambiente? Fundamentamo-nos na obra de Maingueneau (2008). Os resultados obtidos na análise desse discurso revelaram que o enunciador é um conscientizador que busca convencer os coenunciadores sobre os cuidados com o planeta Terra de um modo melancólico, contrastando com a veia cômica da maioria das tirinhas.

Palavras-chave: tirinha; discurso; ethos; cena de enunciação. 